\title{
Evidence for Long-Lasting Cholinergic Control of Gap Junctional Communication between Adrenal Chromaffin Cells
}

\author{
Agnès 0. Martin, ${ }^{1,2}$ Marie-Noëlle Mathieu, ${ }^{1}$ and Nathalie C. Guérineau ${ }^{1}$ \\ ${ }^{1}$ Institut National de la Santé et de la Recherche Médicale (INSERM) Unité 469, Centre National de la Recherche Scientifique/INSERM de Pharmacologie et \\ d'Endocrinologie, 34094 Montpellier Cedex 5, France, and 2Division of Molecular Neurobiology, National Institute for Medical Research, London \\ NW7 1AA, United Kingdom
}

\begin{abstract}
We investigated long-lasting interactions that may occur between two forms of intercellular signaling: cholinergic synaptic transmission and gap junction-mediated coupling in the rat adrenal medulla. The junctional coupling between chromaffin cells was studied during reduced or blocked synaptic transmission in adrenal slices. First, cholinergic synaptic activity was reduced by pharmacological treatment. Bath-application of the nicotinic receptor antagonists hexamethonium, the oxystilbene derivative F3, or $\alpha$-bungarotoxin, acting at distinct neuronal-like postsynaptic nicotinic acetylcholine receptors (nAChRs), significantly increased the incidence of Lucifer yellow passage (dye coupling) between chromaffin cells ( $p>0.7$ in treated slices vs $p=0.4$ in controls). Dye coupling was associated with an elevated macroscopic conductance of the junctional current measured by dual patch-clamp. Pharmacological inhibition of protein trafficking from the trans-Golgi network to the plasma membrane by either brefeldin A or nocodazole pretreatment prevented the effects of nAChR antagonists on dye coupling. Interestingly, this upregulation of gap junction-mediated coupling in response to reduced synaptic activity is of physiological relevance, because it is found in the newborn rat, in which cholinergic synaptic transmission has not yet matured. This mechanism may also be of importance in pathological conditions, because chronic blockade of synaptic transmission after surgical denervation of the adrenal gland also resulted in increased dye coupling between chromaffin cells. In conclusion, our pharmacological, physiological, and pathological data concur to demonstrate that gap junction-mediated intercellular communication between chromaffin cells undergoes persistent adaptation in response to impairment of synaptic activity. These results strongly suggest that gap junctional communication between chromaffin cells is under tonic inhibitory control exerted by cholinergic synaptic inputs.
\end{abstract}

Key words: synaptic transmission; gap junctions; nicotinic receptors; rat adrenal slices; splanchnectomized rats; dye coupling; neonates; hexamethonium; brefeldin A; nocodazole

\section{Introduction}

In integrated biological systems, the precise coordination of cellular signals arising from distinct inputs is critical in maintaining physiological function. In the nervous system, cross talk between chemical synapses and gap junction-mediated cell-to-cell communication is so pervasive (Haydon, 2001) that it is no longer tenable to investigate the mechanisms of neuronal signal integration without considering the intricate interactions between both systems of intercellular contacts. Although synapses represent the main mode of interneuronal communication, it is now well established that gap junctions are widely expressed in neurons (Rozental et al., 2000; Schmitz et al., 2001). The coexistence of synapses and gap junctions in the same cell has raised the question of functional links that may exist between these two forms of cellular communication. Several reports have described short-term

Received Dec. 23, 2002; revised Feb. 12, 2003; accepted Feb. 18, 2003.

This work was supported by grants from the Institut National de la Santé et de la Recherche Médicale, Région Languedoc-Roussillon, Association pour la Recherche sur le Cancer, and Fondation pour la Recherche Médicale. We thank Drs. U. Gerber and P. Mollard for critical reading of this manuscript and M. Passama, A. Carrette, and D. Haddou for their excellent technical assistance. We thank Dr. C. Gotti for kindly providing the F3 compound.

Correspondence should be addressed to Nathalie C. Guérineau, Institut National de la Santé et de la Recherche Médicale (INSERM) Unité 469, Centre National de la Recherche Scientifique/INSERM de Pharmacologie et d'Endocrinologie, 141 rue de la Cardonille, 34094 Montpellier Cedex 5, France. E-mail: nathalie.guerineau@ccipe.cnrs.fr. Copyright (C) 2003 Society for Neuroscience $\quad 0270-6474 / 03 / 233669-10 \$ 15.00 / 0$ regulatory effects of acute application of neurotransmitters or neuromodulators on interneuronal gap junctional communication (Piccolino et al., 1982, 1984; Pereda et al., 1992; Hatton and Yang, 1996; McMahon and Mattson, 1996; Shinohara et al., 2000; Lagostena et al., 2001). Physiological or electrically induced activation of synaptic inputs also acutely modulates intercellular coupling (Hatton and Yang, 1996, 2001; Hatton, 1997), indicating that modulation of coupling by synaptically released factors likely occurs in situ between excitable cells (Hatton, 1998). The effects on gap junction coupling primarily result from the activation within minutes of intracellular messenger systems $\left(\mathrm{Ca}^{2+}\right.$, cAMP, cGMP), suggesting the modulation of junctional conductances of anchored channels rather than the targeting of a downstream step affecting connexon number or trafficking. We report here that in addition to this very short-term control of gap junctional communication, synaptic inputs can also exert a long-term regulation of the extent of gap junction-mediated intercellular coupling between excitable cells. We addressed this issue in rat adrenal chromaffin cells, because the medulla presents unique features providing an ideal preparation for studying the interactions between gap junctions and synaptic activity. Indeed, although chromaffin cell secretory activity is chiefly regulated trans-synaptically via the splanchnic nerve (Axelrod, 1971), the 
interaction of gap junction-mediated signal propagation with synaptic transmission represents a complementary mechanism for the exocytosis of catecholamines, as we have shown in slices (Martin et al., 2001). To demonstrate the effect of cholinergic synaptic activity on gap junction-mediated communication in the adrenal medulla, the junctional coupling between chromaffin cells was examined in slices in which either the synaptic inputs or the nicotinic receptors were manipulated. We found an increase in dye coupling after pharmacologically impairing or chronically disrupting synaptic transmission to chromaffin cells. This upregulation was abolished when protein delivery to the plasma membrane was inhibited by agents that disrupt the Golgi apparatus. Of particular physiological interest is the situation observed in neonatal rats. At birth, dye coupling was upregulated, as could be expected in light of the immaturity of neurochemical synapses. We propose that gap junctional coupling in the adrenal medulla undergoes long-term plasticity as a compensatory response under conditions of reduced cholinergic synaptic transmission. Furthermore, our results indicate that under control conditions, gap junctional coupling is under tonic inhibitory control.

\section{Materials and Methods}

Adrenal slice preparation. Acute adrenal slices were prepared as reported previously (Martin et al., 2001). Briefly, the adrenal glands were removed from newborn and adult (12- to 16-week-old) female Wistar rats killed by decapitation after cervical dislocation. After keeping the glands in ice-cold saline for $2 \mathrm{~min}$, a gland was glued onto an agarose cube and transferred to the stage of a vibratome (Microslicer, DTK-1000, D.S.K, Dosaka, Kyoto, Japan). Slices of $250 \mu \mathrm{m}$ thickness were then cut with a razor blade, transferred to a storage chamber maintained at $32^{\circ} \mathrm{C}$ containing Ringer's saline (in mu: $125 \mathrm{NaCl}, 2.5 \mathrm{KCl}, 2 \mathrm{CaCl}_{2}, 1 \mathrm{MgCl}_{2}, 1.25$ $\mathrm{NaH}_{2} \mathrm{PO}_{4}, 26 \mathrm{NaHCO}_{3}$, and 12 glucose), and buffered to $\mathrm{pH} 7.4$. The saline was continuously bubbled with carbogen $\left(95 \% \mathrm{O}_{2}-5 \% \mathrm{CO}_{2}\right)$. In some experiments, acute slices were prepared from splanchnectomized adult female rats $(n=5)$. The left adrenal gland was denervated by transecting the left splanchnic nerve (surgery performed by Iffa Credo, L'Arbresle, France). Splanchnectomized rats were used 2-4 weeks after surgery. The efficacy of the adrenal denervation was confirmed by the absence of postsynaptic currents in chromaffin cells during electrophysiological recordings.

For optical and/or electrophysiological recordings, slices were then transferred to a recording chamber attached to the stage of an upright microscope fitted with differential interference contrast optics (Axioskop FS; Zeiss, Le Pecq, France) and continuously superfused with Ringer's saline at $30^{\circ} \mathrm{C}$.

Real-time imaging of cytosolic calcium. $\mathrm{Ca}^{2+}$ changes were monitored using a confocal laser scanning microscope equipped with an $\mathrm{Ar} / \mathrm{Kr}$ laser (Odyssey XL with InterVision 1.5.1 software; Noran Instruments Inc., Middleton, WI) (Guérineau et al., 1998). Cells were viewed with a $63 \times$ 0.9 numerical aperture (NA) achroplan water immersion objective (Zeiss). For measurements of intracellular calcium concentration $\left(\left[\mathrm{Ca}^{2+}\right]_{\mathrm{i}}\right)$, the largest detection slit $(100 \mu \mathrm{m})$ of the confocal microscope was used, giving bright images with a $3.1 \mu \mathrm{m}$ axial resolution. Slices were loaded with the $\mathrm{Ca}^{2+}$-sensitive fluorescent probe Oregon Green 488 BAPTA-1 by intermittent exposure to $15 \mu \mathrm{M}$ Oregon Green 488 BAPTA-1 acetoxymethyl ester (Molecular Probes, Eugene, OR) for $20-30 \mathrm{~min}$ at $32^{\circ} \mathrm{C}$, delivered onto a cell field with a blunt pipette (Bonnefont et al., 2000). Oregon Green 488 BAPTA-1 was excited through a $488 \mathrm{~nm}$ bandpass filter, and the emitted fluorescence was collected through a $515 \mathrm{~nm}$ barrier filter. To follow the time course of Oregon Green 488 BAPTA-1 emission changes, the bright-over-time tool of the software package was applied to live images (120 images per second, averaging four frames). $\left[\mathrm{Ca}^{2+}\right]_{i}$ changes were expressed as the $F / F m i n$ ratio, where $F \min$ was the minimum fluorescence intensity measured during the recording. Acquired data and images were then processed for analysis with Igor Pro 3.16 (Wavemetrics Inc., Lake Oswego, OR) and NIH Image 1.6.0 software.

Electrophysiology. All experiments were performed in the whole-cell configuration of the patch-clamp technique (Hamill et al., 1981). Patch pipettes were pulled to a resistance of 5-8 $\mathrm{M} \Omega$ from borosilicate glass ( $1.5 \mathrm{~mm}$ outer diameter; $1.17 \mathrm{~mm}$ inner diameter) and filled with the following internal solution (in $\mathrm{mM}$ ): 140 potassium-gluconate, 2 $\mathrm{MgCl}_{2}, 1.1$ EGTA, and 5 HEPES, titrated to $\mathrm{pH} 7.2$ with $\mathrm{KOH}$. The membrane potential of chromaffin cells was recorded under currentclamp conditions using an EPC-9 patch-clamp amplifier (Heka Electronik, Lambrecht/Pfalz, Germany) and filtered at $3 \mathrm{kHz}$. Spontaneous EPSCs were recorded in chromaffin cells voltage-clamped at $-80 \mathrm{mV}$ in normal external $\left[\mathrm{K}^{+}\right]$and were filtered at $1 \mathrm{kHz}$. Signals were acquired and analyzed using Pulse and PulseFit software (version 8.5; Heka Electronik) on a G4 Macintosh computer. For combined experiments in which membrane potential was simultaneously recorded with $\mathrm{Ca}^{2+}$ events, Oregon Green 488 BAPTA- 1 in free acid form $(10 \mu \mathrm{M})$ was directly added to the internal pipette solution (Martin et al., 2001). Membrane potentials of chromaffin cell pairs were recorded under current-clamp conditions using an EPC-9 dual patch-clamp amplifier (Heka Electronik) and filtered at $3 \mathrm{kHz}$. Intercellular junctional currents were monitored under dual voltage-clamp conditions (Neyton and Trautmann, 1985) using a modified intrapipette solution (in mM: $140 \mathrm{Cs}^{+}$-gluconate, $2 \mathrm{MgCl}_{2}, 1.1$ EGTA, and 5 HEPES). To determine the macroscopic junctional conductance $\left(G_{\mathrm{j}}\right)$, the $I-V$ curve in which $I_{\mathrm{j}}$ amplitude was plotted as a function of the transjunctional voltage $\left(V_{\mathrm{j}}\right)$ was fitted by a computed linear regression, $y=a x+b$ (where $y$ corresponds to $I_{\mathrm{j}}$ and $x$ to $V_{\mathrm{j}}$ ). $G_{\mathrm{j}}$ was then given by the slope $(a)$ of the linear regression.

Lucifer yellow diffusion. The fluorescent dye Lucifer yellow (LY)-CH (1 $\mathrm{mm}$ ) (LY-CH is the hydrazine form of the dye) was introduced into chromaffin cells using patch pipettes. Dye transfer between gap junctioncoupled cells was visualized with confocal microscopy using the $488 \mathrm{~nm}$ centered wavelength of the laser beam. The extent of LY diffusion between chromaffin cells was estimated by counting the number of labeled cells. The probability of LY diffusion was expressed as a ratio corresponding to the number of injected cells that show dye transfer to adjacent cells over the total number of injected cells. Transmitted images were acquired using the longer wavelength of the laser beam $(647 \mathrm{~nm})$, which penetrated deeply into adrenal slices.

Immunofluorescence and image processing. After dye coupling experiments, adrenal slices were fixed in $4 \%$ paraformaldehyde for $1 \mathrm{hr}$ at room temperature before immunofluorescence. Background noise was reduced by quenching free aldehyde groups with $50 \mathrm{~mm} \mathrm{NH}_{4} \mathrm{Cl}$ in PBS, pH 7.4, two times for 15 min each. Permeabilization was achieved with PBS containing $0.5 \%$ Triton X-100 and $20 \%$ horse serum for $1 \mathrm{hr}$ at room temperature. Adrenal slices were then incubated with the primary antibodies to trans-Golgi network 38 (TGN38) (1/100; Transduction Laboratories product; Interchim, Montluçon, France) or $\beta$-tubulin $(1 / 2000$; Sigma, St. Louis, MO) for $48 \mathrm{hr}$ at $4^{\circ} \mathrm{C}$ in PBS plus $0.1 \%$ Triton $\mathrm{X}-100$ plus $20 \%$ horse serum. The slices were washed three times for $10 \mathrm{~min}$ in PBS and incubated with the secondary antibody (1/1000 Cy3-conjugated mouse IgG; Jackson product; Interchim) for $2 \mathrm{hr}$ at room temperature in PBS plus $0.1 \%$ Triton X-100 plus $20 \%$ horse serum. Slices were washed three times for $10 \mathrm{~min}$ with PBS and mounted on glass coverslips in Mowiol. 1,4-diazobicyclo-[2.2.2]-octane (2.5\%; Sigma) was added to the mounting medium to reduce fading. Immunolabeling without primary antibody was used as a control. Slices were imaged with the Odyssey XL (Noran Instruments Inc.) laser confocal microscope. The $568 \mathrm{~nm}$ line of the laser beam was selected, and the emitted fluorescence was collected through the $590 \mathrm{~nm}$ barrier filter (low-pass filter). Cells were viewed with a $100 \times 1.3$ NA plan-neofluar oil immersion objective (Zeiss). For image acquisition, the $25 \mu \mathrm{m}$ detection slit of the confocal microscope was used, giving bright images with a $0.7 \mu \mathrm{m} z$-axis resolution. Optical slices of the chromaffin cells were recorded using the normal scan mode (30 images per second, averaging 256 frames) with an image size of $308 \times 239$ pixels and a $400 \mathrm{nsec}$ dwell rate per pixel. To improve the resolution of confocal images, extraction of unblurred images was performed by a two-dimensional blind deconvolution (deconvolution module of the InterVision software package). 
Solutions and chemicals. The nicotinic receptor blockers hexamethonium (Sigma), F3, and $\alpha$-bungarotoxin ( $\alpha$-Bgt; Sigma) were bathapplied ( $5 \mathrm{~min}$ before testing their effects on spontaneous EPSCs and 30 min before dye spread experiments). The oxystilbene derivative F3 compound was synthetized in Dr. Francesco Clementi's laboratory (Consiglio Nazionale delle Ricerche, Cellular and Molecular Pharmacology Center, University of Milan, Milan, Italy) and was first reported to be a selective ligand for neuronal nicotinic $\alpha$-bungarotoxin-sensitive receptors (Gotti et al., 1998). LY, the gap junction blocker carbenoxolone, and the nonselective $\mathrm{P} 2$ purinergic receptor antagonists were purchased from Sigma. Brefeldin A (BFA) $(2 \mu \mathrm{g} / \mathrm{ml}$; purchased from Fluka, L'isle d'Abeau Chesnes, France) and nocodazole ( $25 \mu \mathrm{m}$; obtained from TebuFrance, Le Perray en Yveline, France) were used to inhibit the Golgi apparatus (Dinter and Berger, 1998). To fully disrupt the Golgi complex and microtubules, adrenal slices were treated either with BFA or with nocodazole for at least $30 \mathrm{~min}$ at $37^{\circ} \mathrm{C}$ before and during incubation in hexamethonium-containing saline.

Statistics. Numerical data are expressed as means \pm SEM. The Student's $t$ test was used to compare means when appropriate. Differences between groups were assessed by using the nonparametric Mann-Whitney $U$ test. Percentages were compared using a contingency table and the $\chi^{2}$ test. Differences of $p<0.01$ were considered significant.

\section{Results}

As reported recently, the presence of gap junctions between chromaffin cells can be accurately determined by examining the diffusion of the low-molecular-weight fluorescent dye Lucifer yellow (Martin et al., 2001). This approach was used here to study the gap junction-mediated intercellular coupling between chromaffin cells under various experimental conditions, in which the level of synaptic transmission at the splanchnic nerve terminals was manipulated.

\section{Increase in gap junctional communication between \\ chromaffin cells after acute impairment of synaptic excitatory cholinergic transmission}

When chromaffin cells were voltage-clamped at $-80 \mathrm{mV}$, spontaneous inward synaptic currents were observed that are likely to reflect acetylcholine release from the presynaptic terminals contacting chromaffin cells (Barbara and Takeda, 1996). In control saline $\left(2.5 \mathrm{mM} \mathrm{K}^{+}\right), 12 \%$ of chromaffin cells exhibited spontaneous EPSCs when recorded over $10 \mathrm{~min}$ ( $n=75$ cells) (Fig. $1 \mathrm{Aa}-c$, left traces). The mean EPSC amplitude and frequency were $89.6 \pm 5.6 \mathrm{pA}(n=252 \mathrm{EPSCs}$, nine cells $)$ and $0.08 \pm 0.04 \mathrm{~Hz}$ ( $n=9$ cells) (range, $0.001-0.34 \mathrm{~Hz}$ ), respectively. It has been reported previously that inward synaptic currents are mediated by the activation of neuronal-like postsynaptic nicotinic acetylcholine receptors (nAChRs) (Barbara and Takeda, 1996). Because the $\alpha 3$ subunit-containing nAChRs represent the major subtype transducing the ACh-evoked postsynaptic electrical response in chromaffin cells (Nooney and Feltz, 1995), we tested the effect of hexamethonium, which specifically targets this receptor subtype. Bath-application of hexamethonium $(200 \mu \mathrm{M})$ significantly reduced the amplitude and frequency of spontaneous EPSCs (Fig. $1 \mathrm{Aa}$, right trace and histograms). The percentage of inhibition of both EPSC frequency and amplitude was $41.4 \pm$ 10.6 and $56.6 \pm 10.5 \%$, respectively $(n=8$ cells recorded before and in the presence of hexamethonium). These effects were partly reversible within 10-20 min (data not shown). The frequency of spontaneous EPSCs was also significantly decreased in the presence of the oxystilbene derivative F3 ( $30 \mathrm{nM}$, bath-application) (Fig. $1 A b$, right trace), a compound recently reported to antagonize $\alpha 3$ subunit-containing nAChRs in the rat adrenal gland (Di Angelantonio et al., 2000). No significant effect on the amplitude of the remaining EPSCs was observed $(n=10)$. The effect of F3
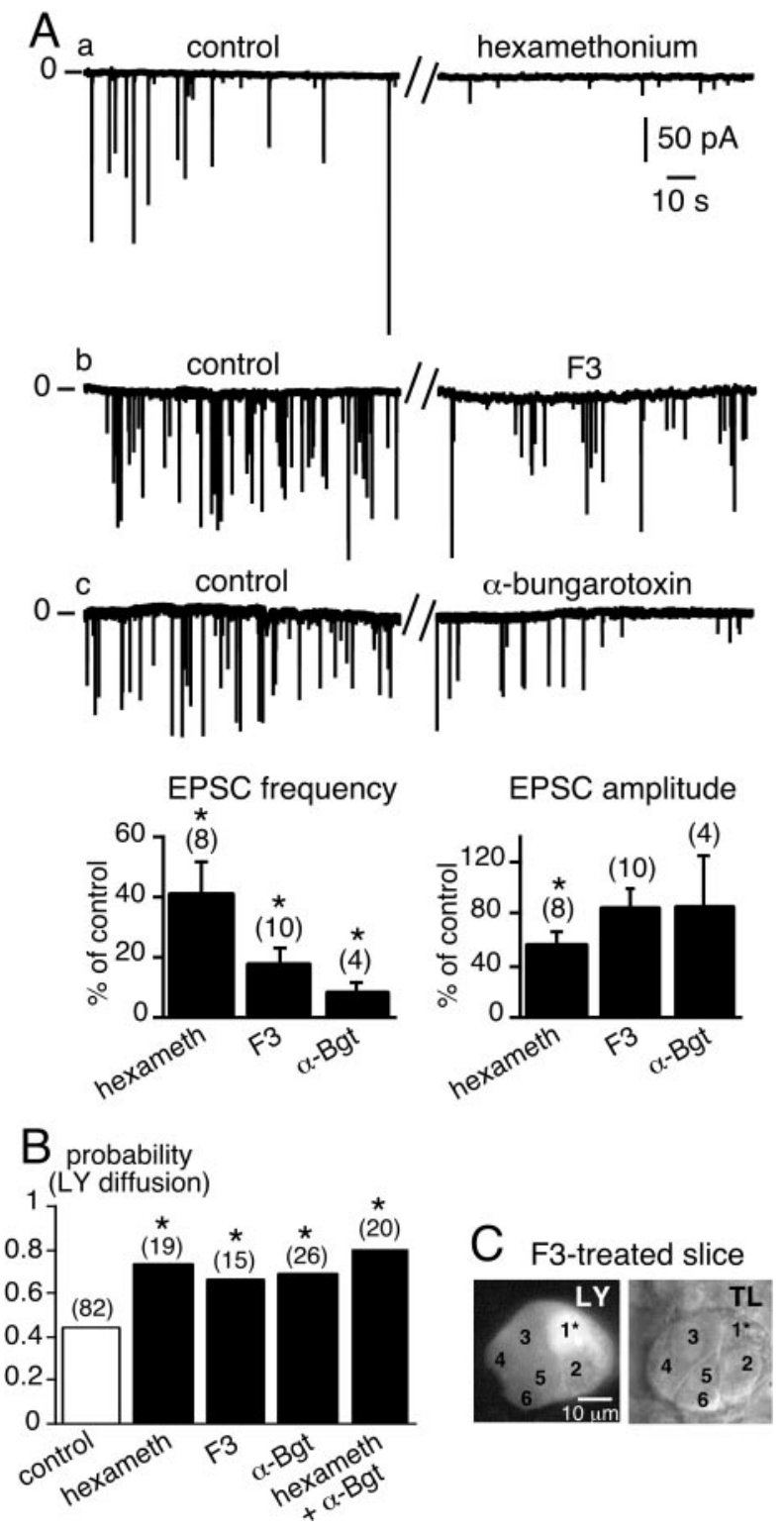

Figure 1. Acute impairment of synaptic activity-induced upregulation of LY diffusion between chromaffin cells. $A, a-c$, Spontaneous EPSCs recorded in chromaffin cells voltageclamped at $-80 \mathrm{mV}$ in normal saline ( $2.5 \mathrm{~mm}$ external $\mathrm{K}^{+}$) (left traces) and in the presence of three bath-applied nAChR blockers, hexamethonium (200 $\mu \mathrm{M})$, the oxystilbene derivative F3 (150 nM), and $\alpha$-bungarotoxin $(1.5 \mu \mathrm{m})$ (right traces). The histograms summarize the effects of the blockers on EPSC frequency and amplitude. ${ }^{*} p<0.01$ compared with control values. $B$, Histograms illustrating the increase in the probability of $L Y$ diffusion between chromaffin cells in slices treated with nAChR blockers. The number of recorded cells for each experimental condition is indicated in parentheses. ${ }^{*} p<0.01$ compared with control values. C, Example of widespread LY diffusion within a cell cluster in a F3-treated slice. TL, Transmitted light image. Five neighboring chromaffin cells in the same optical plane were labeled with LY after dye injection into the cell $1^{*}$.

was reversible within several minutes (data not shown). Because both hexamethonium and F3 did not fully inhibit spontaneous EPSCs, and because rat adrenomedullary chromaffin cells also express the $\alpha 7$ subunit-containing AChRs (Rust et al., 1994; Criado et al., 1997; Mousavi et al., 2001), the snake neurotoxin $\alpha$-bungarotoxin, an irreversible antagonist of $\alpha 7 \mathrm{nAChRs}$ (Sine, 1997), was tested. As illustrated in Figure $1 A c, \alpha$-Bgt $(1.5 \mu \mathrm{M})$ significantly decreased EPSC frequency $(p<0.01 ; n=4)$. These results indicate that hexamethonium, F3, and $\alpha$-Bgt efficiently 
reduce excitatory cholinergic synaptic transmission between presynaptic nerve terminals and chromaffin cells.

To investigate possible signaling interactions between synaptic transmission and gap junction-mediated intercellular coupling, we next studied the effects of applying hexamethonium, F3, or $\alpha$-Bgt for 10-30 min on LY diffusion between chromaffin cells. As shown in Figure $1 B$, the probability of observing LY diffusion between nearby chromaffin cells was significantly increased when slices were incubated with nAChR blockers $(0.74$, 0.67 , and 0.70 for hexamethonium, F3, and $\alpha$-Bgt, respectively, vs 0.44 in control slices; $p<0.01)$. Incubation in a medium containing a combination of hexamethonium and $\alpha$-Bgt did not significantly increase the probability of dye coupling between chromaffin cells compared with the effect of either blocker alone (Fig. $1 B)$. In the presence of $\mathrm{nAChR}$ antagonists, LY-labeled cell clusters (more than or equal to three cells) were observed more frequently $(21.1 \%$ in hexamethonium-treated slices vs $2.4 \%$ in control slices). An example of prominent dye coupling in an F3bathed slice is illustrated in Figure $1 C$.

Could this upregulation of dye coupling be mimicked by other synaptically released excitatory factors? Acetylcholine and ATP are stored together in some synaptic vesicles, including those in sympathetic splanchnic nerve terminals (Zimmermann, 1994). We therefore investigated the effect of blocking postsynaptic purinergic receptors in chromaffin cells on the spreading of LY. Thirty minutes of incubation in the presence of $100 \mu \mathrm{M}$ suramin, a nonselective blocker of $\mathrm{P} 2$ purinergic receptors, modified neither the incidence of dye coupling $(p=0.44 ; n=16$, data not shown) when compared with control slices (0.44) nor the extent of coupling (data not shown). To further investigate the role of potential non-nicotinic purinergic EPSCs, slices were exposed to suramin $(100 \mu \mathrm{M})$, hexamethonium $(200 \mu \mathrm{M})$, and $\alpha$-Bgt $(1.5$ $\mu \mathrm{M})$ for at least $30 \mathrm{~min}$ before LY injections. Dye coupling to adjacent chromaffin cells was observed in $73.7 \%$ of the injected cells $(n=19)$. This was similar to the percentage found with saline-containing $\mathrm{nAChR}$ antagonists $(p>0.01)$. This result indicates that the increase in gap junctional coupling is mediated by a specific pathway involving postsynaptic nAChRs and is of interest when considering that acetylcholine is the main synaptically released transmitter that stimulates catecholamine exocytosis in chromaffin cells.

To confirm that the increase in dye coupling reflects increased functional communication between chromaffin cells, depolarization-evoked action potentials were triggered in a single chromaffin cell, and subsequent $\left[\mathrm{Ca}^{2+}\right]_{i}$ signals were simultaneously monitored in neighboring cells in hexamethonium-treated slices (Fig. 2A). As reported previously (Martin et al., 2001), this paradigm led to propagated electrically triggered $\left[\mathrm{Ca}^{2+}\right]_{\mathrm{i}}$ rises between gap junction-coupled cells. As a result, synchronous multiple $\left[\mathrm{Ca}^{2+}\right]_{\mathrm{i}}$ rises were frequently observed in neighboring cells (68.7\% of cell fields; $n=22$ of 32) (Fig. 2 B) in the presence of hexamethonium. In untreated slices, the percentage dropped to $48.1 \%$ ( $n=13$ of 27 ), as shown previously (Martin et al., 2001). In addition, the number of neighboring cells in which the $\left[\mathrm{Ca}^{2+}\right]_{\mathrm{i}}$ rose in response to a single cell depolarization was higher in hexamethonium-containing saline than under control conditions. These data are in agreement with those reported in Figure 1.

All of these results show that reduced excitatory cholinergic synaptic activity resulting in a decrease in postsynaptic nAChR activation rapidly (in $<1 \mathrm{hr}$ ) upregulates gap junctional coupling between chromaffin cells.

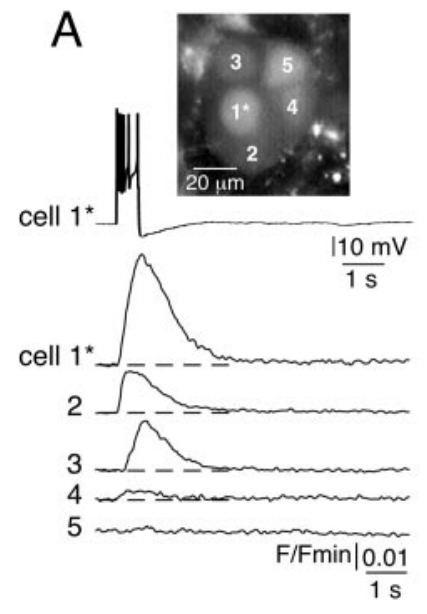

B

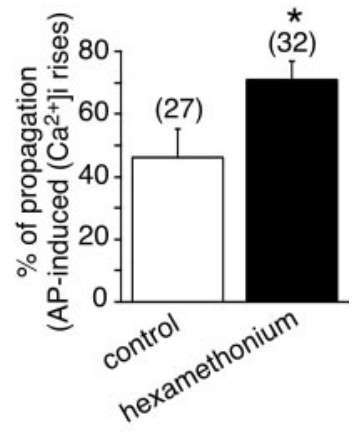

Figure 2. Propagation of action potential-induced $\left[\mathrm{Ca}^{2+}\right]_{i}$ rises between chromaffin cells in hexamethonium-containing saline. $A$, Electrical activity-driven multicellular $\left[\mathrm{Ca}^{2+}\right]_{i}$ increases were visualized by real-time scanning laser confocal imaging (120 images per second, averaging 4 frames) in five chromaffin cells loaded with Oregon Green 488 BAPTA-1 as the $\mathrm{Ca}^{2+}$ sensitive fluorescent probe. The adrenal slice was continuously perfused with $200 \mu \mathrm{m}$ hexamethonium (for at least $30 \mathrm{~min}$ before recording). The plots of relative Oregon Green 488 BAPTA-1 emission changes show a $\left[\mathrm{Ca}^{2+}\right]_{\mathrm{i}}$ rise in either the stimulated cell $\left(1^{*}\right.$, burst of action potentials triggered by an injection of a $500 \mathrm{msec}$ depolarizing current) or three nearby cells (cells $2-4$ ). Note that cell 5 remained silent. Dotted lines indicate the baseline. $B$, Histogram illustrating the percentage of cell fields in which the $\left[\mathrm{Ca}^{2+}\right]_{\mathrm{i}}$ rise was propagated to adjacent cells in control and hexamethonium-treated slices. ${ }^{*} p<0.01$ compared with control.

\section{Electrical coupling and gap junction currents between} chromaffin cells in hexamethonium-treated slices: increased incidence of highly electrically coupled cells

What is the mechanism underlying the short-term increase in gap junction-mediated coupling between chromaffin cells in the presence of $\mathrm{nAChR}$ antagonists? To address this issue, membrane potentials were recorded from chromaffin cell pairs using the dual patch-clamp technique. In $68.2 \%$ of cell pairs $(n=15$ of 22$)$, the voltage changes in response to hyperpolarizing/depolarizing current injected into the stimulated cell were reflected as variably attenuated responses in the unstepped cell (Fig. 3A, B, left traces) and vice versa (right traces). In $80 \%$ of coupled pairs, an action potential in the injected cell induced only a small depolarization in the neighboring cell (Fig. $3 A$ ), indicating weak coupling, whereas in the remaining pairs, robust coupling led to the transmission of suprathreshold responses, resulting in action potentials (Fig. 3B). Consequently, the coupling ratios exhibited a wide distribution range of 0.01-0.96 (mean, $0.24 \pm 0.09$; $n=15$ coupled pairs) (Fig. 3C) that appeared to be bimodal. This reflects the presence of two chromaffin cell populations, a weakly coupled cell population, and a highly coupled cell population. It is interesting to note that the value of the coupling ratio for a given cell pair remained constant independent of the amplitude or polarity of the current step. These findings were confirmed in $\mathrm{Cs}^{+}$-loaded chromaffin cell pairs voltage-clamped at $-60 \mathrm{mV}$. Junctional currents were recorded in $64.7 \%$ (11 of 17) of the cell pairs (Fig. 4 ), a value similar to that found in control slices [61\% (Martin et al., 2001)] ( $p>0.01)$. Delivering voltage steps with command pulses of both polarities induced macroscopic junctional currents $\left(I_{\mathrm{j}}\right)$ in the unstepped cell that appeared to remain constant for the duration of the step, but again exhibiting variable degrees of attenuation. In $56.5 \%$ of recorded pairs $(n=6), I_{\mathrm{j}}$ amplitude did not exceed several picoamperes (Fig. $4 A$ ), whereas in $45.5 \%$ of cell pairs $(n=5), I_{\mathrm{j}}$ could reach $1-2 \mathrm{nA}$ (Fig. $\left.4 B\right)$. When plotted as a function of the transjunctional potential, the $I-V$ curve of $I_{\mathrm{j}}$ 

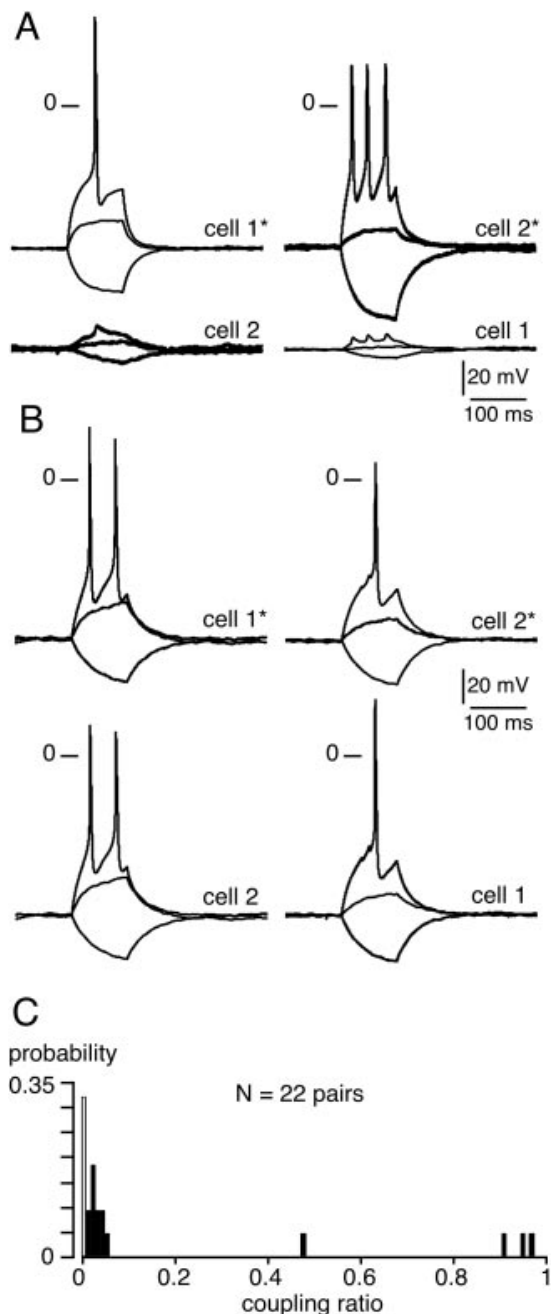

Figure 3. Electrical coupling between chromaffin cell pairs in hexamethonium-containing extracellular medium. Membrane potential was monitored in chromaffin cell pairs using the dual patch-clamp technique. $A$, Illustration of a cell pair in which the triggering of action potentials in cell 1 resulted in small membrane depolarizations in cell 2 (left traces) and vice versa (right traces). The two cells were current-clamped at $-65 \mathrm{mV}$. B, Example of a cell pair in which action potentials were transmitted to the nonstimulated cell. The two cells were currentclamped at $-68 \mathrm{mV}$. C, Histograms illustrating the wide distribution range of the coupling ratio calculated in 22 chromaffin cell pairs ( 7 noncoupled pairs and 15 coupled pairs) from currentclamp measurements of voltage amplitude in response to a hyperpolarizing current injection in cell 1 (stepped cell) and cell 2 (target cell) (from 0 for noncoupled pairs to 1 for highly coupled pairs).

displayed a linear relationship within the membrane potential range of -200 to $+150 \mathrm{mV}$. The curve used to fit the data was derived from a linear regression, given a mean macroscopic conductance of $\sim 42 \mathrm{pS}(n=6)$ for the weak coupling and $\sim 12 \mathrm{nS}$ $(n=5)$ for the robust coupling (Fig. 4C). Compared with our previous study (Martin et al., 2001), the main effect of hexamethonium was to significantly increase the incidence of highly electrically coupled cells. Indeed, a robust $I_{\mathrm{j}}$ was observed less frequently under control conditions (20 vs $45 \%$ in control and hexamethonium-treated slices, respectively) $(p<0.01)$ (Fig. $4 D, E)$.

Effects of inhibiting connexon trafficking to the plasma membrane by disrupting the trans-Golgi network and microtubules

We also examined possible mechanisms that could underlie the increase in macroscopic $I_{\mathrm{j}}$ conductance. Based on the fact that the
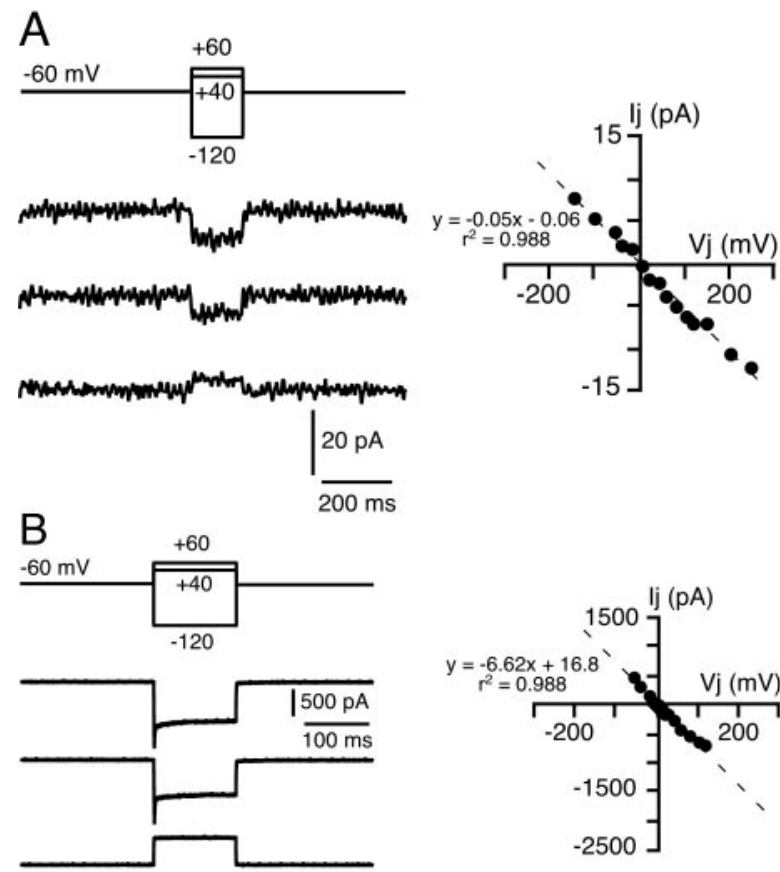

C
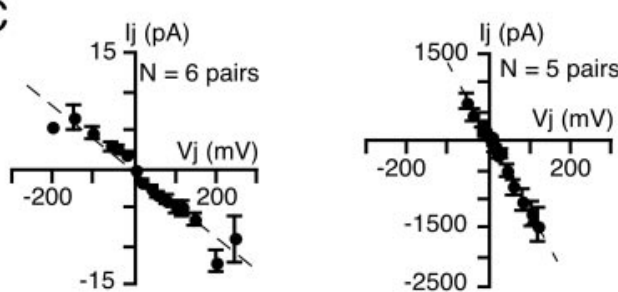

D
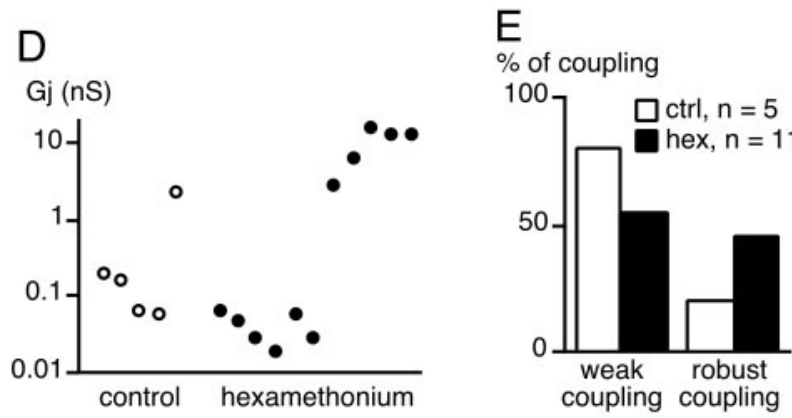

Figure 4. Macroscopic junctional currents $l_{j}$ between chromaffin cell pairs in hexamethonium-containing saline. Junctional currents $\left(l_{\mathrm{j}}\right)$ were measured in $C s^{+}$-loaded (140 $\mathrm{mm} \mathrm{Cs}^{+}$-gluconate) cell pairs voltage-clamped at $-60 \mathrm{mV}$ (transjunctional potential from -120 to $+60 \mathrm{mV} ; 150 \mathrm{msec}$ duration). $A$, Example of a low $l_{\mathrm{j}}$ amplitude indicating weak coupling (macroscopic junctional conductance, $G_{\mathrm{j}}=50 \mathrm{pS}$, as calculated from the slope of the $I-V$ curve). $B$, Robust electrical coupling evidenced by high $I_{\mathrm{j}}$ amplitude $\left(G_{\mathrm{j}}=6.6 \mathrm{nS}\right)$. C, I-V relationships from pooled data of six and five cell pairs exhibiting weak and robust coupling, respectively. The linear regression used to fit the data (dotted line) was $y=-0.042 x-0.41$ $\left(r^{2}=0.94\right)$ for the weak coupling and $y=-12.4 x-6.37\left(r^{2}=0.99\right)$ for the robust coupling, given a $G_{j}$ of $42 \mathrm{pS}$ and $12.4 \mathrm{nS}$, respectively. $D$, Pooled data of $G_{\mathrm{j}}$ calculated in five cell pairs bathed in control saline and 11 pairs in hexamethonium-containing saline (logarithmic scale on $y$-axis). The determination of $G_{\mathrm{j}}$ in control medium includes data from Martin et al. (2001). E, Percentage of appearance of weak and robust coupling and control (ctrl) and hexamethonium (hex)-treated slices.

effects of nAChR antagonists occurred within $30 \mathrm{~min}$, we first tested the hypothesis of a protein trafficking-mediated effect by manipulating intracellular connexon trafficking. As shown recently (Lauf et al., 2002), newly synthesized connexons are transported from the Golgi apparatus to the plasma membrane via 
vesicular transport along microtubules. Because the TGN is involved in the sorting and targeting of proteins to the plasma membrane, we first attempted to inhibit membrane insertion of new connexons by disrupting the TGN. This was achieved by treating the adrenal slices for at least $30 \mathrm{~min}\left(\right.$ at $\left.37^{\circ} \mathrm{C}\right)$ before and during $\mathrm{nAChR}$ antagonist treatment with BFA $(2 \mu \mathrm{g} / \mathrm{ml})$, an inhibitor of vesicular export from the TGN. BFA has been reported to disassemble the Golgi apparatus into tubules by inhibiting the guanine nucleotide exchange on ADP-ribosylating factors (Helms and Rothman, 1992; Klausner et al., 1992). Golgi disruption was verified by immunolabeling of TGN38, a transmembrane glycoprotein predominantly localized to the TGN (Luzio et al., 1990). As illustrated in Figure 5Aa, in BFA-treated slices, TGN38 appeared homogeneously distributed within the cytosol, whereas it showed the expected perinuclear localization in untreated slices. Under these experimental conditions, the increase in the probability of dye coupling in the presence of hexamethonium was abolished and was not significantly different from that found in control slices $(p>0.01 ; 0.41$ vs 0.44 for BFA-treated and control slices, respectively) (Fig. $5 B)(n=39)$. This result was also confirmed in slices treated with the potent microtubule depolymerizing agent nocodazole $\left(25 \mu \mathrm{M}\right.$, at least $30 \mathrm{~min}$ at $37^{\circ} \mathrm{C}$ before incubation in hexamethonium). As expected, nocodazole treatment strongly disrupted the microtubule network visualized by the immunofluorescent detection of $\beta$-tubulin protein (Fig. $5 A b)$. Similarly to what we found in BFA-treated slices, the probability of observing LY coupling in the presence of hexamethonium dropped to control conditions $(p>0.01 ; 0.44$ for nocodazole-treated and control slices) (Fig. $5 B)(n=29)$. Note that BFA or nocodazole treatment did not modify per se either the resting membrane potential or the ability of chromaffin cells to exhibit spontaneous or electrically evoked action potentials (data not shown).

Together, these results indicate that connexon trafficking from the trans-Golgi network to the plasma membrane is a likely mechanism mediating the effects of hexamethonium on gap junctional coupling between chromaffin cells.

Gap junctional coupling is modulated by the functional state of synaptic transmission: the physiological significance in newborn rats

At birth, the innervation of chromaffin cells by splanchnic nerve fibers is not fully mature (Millar and Unsicker, 1981), although the majority, if not all, of the presynaptic and postsynaptic components are already present prenatally (Daikoku et al., 1977; Tomlinson and Coupland, 1990). Spontaneous synaptic activity was recorded in adrenal slices from newborn rats. In neonates, $\sim 22 \%$ of recorded cells spontaneously exhibited EPSCs (Fig. 6A) $(n=23)$. The mean EPSC amplitude was $35.7 \pm 3.2 \mathrm{pA}(n=59$, five cells), and the frequency was $0.02 \pm 0.01 \mathrm{~Hz}(n=5)$. With respect to LY coupling, the probability of observing dye spreading between chromaffin cells was significantly higher in neonates than in adults $(\sim 0.6$ vs $\sim 0.4$, respectively; $p<0.01)$ (Fig. $6 B)$. LY coupling was indeed mediated by gap junctions, as shown by the dramatic reduction in LY diffusion in the presence of carbenoxolone $(200 \mu \mathrm{M}, 10-60 \mathrm{~min})$ (Fig. 6B), a decoupling agent (Ishimatsu and Williams, 1996). The spatial extent of LY staining was also higher in neonates compared with adult rats. After injecting dye into a single cell, up to four to five adjacent cells were labeled, whereas coupling was confined to one to two cells in adults (Fig. 6C).

What might the physiological significance be for gap junctionmediated coupling in neonates? We reported previously that gap
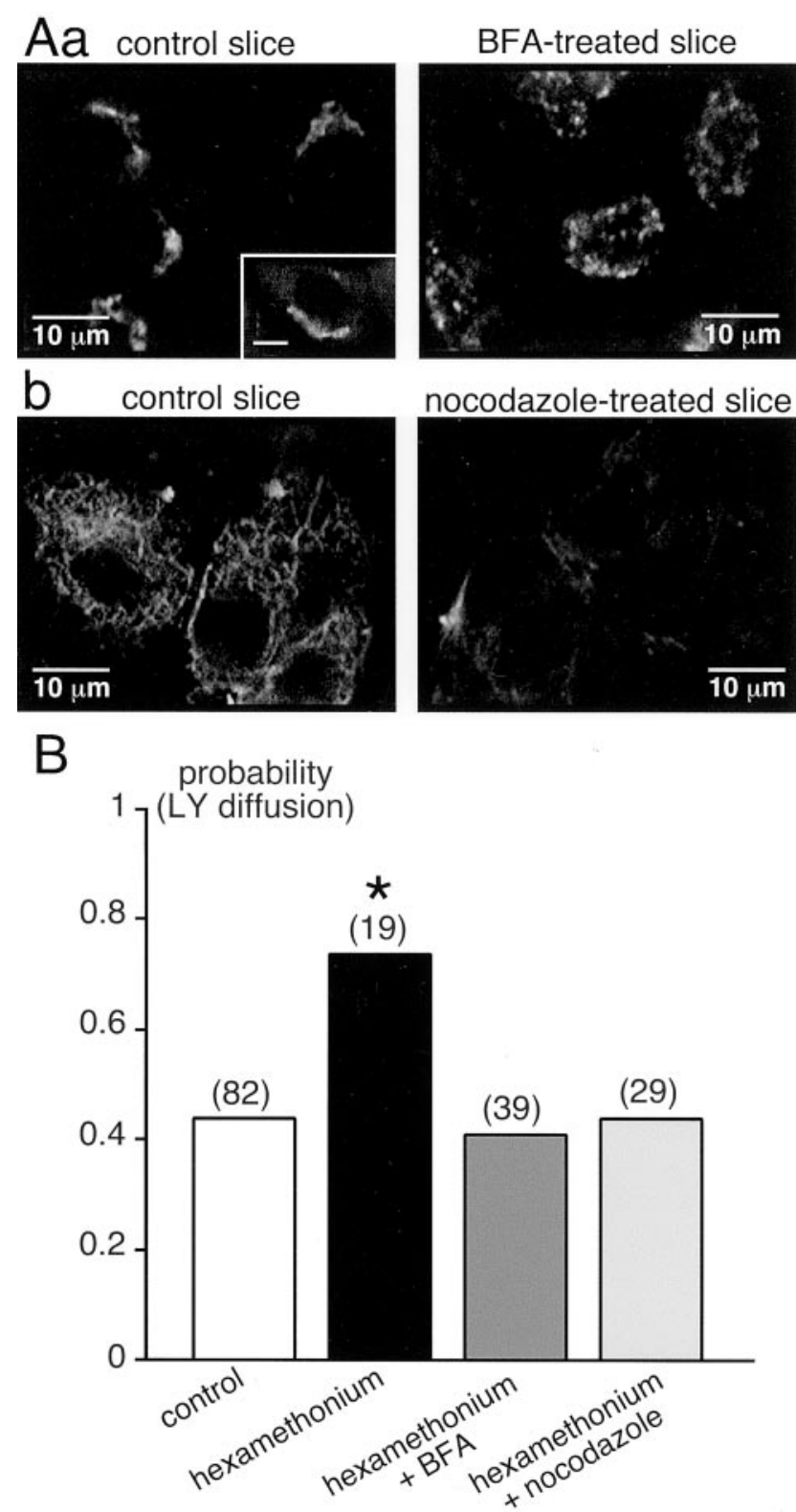

Figure 5. Effect of inhibiting connexon delivery to the plasma membrane on the increase in gap junctional coupling in hexamethonium-treated slices. Connexon trafficking from the Golgi apparatus to the plasma membrane was abolished by treating slices with either BFA ( $2 \mu \mathrm{g} / \mathrm{ml})$ or the cytoskeletal disrupting agent nocodazole $(25 \mu \mathrm{m})$ for at least 30 min before adding 200 $\mu \mathrm{m}$ hexamethonium. $A, a$, Immunofluorescent labeling of the TGN using an antibody directed against TGN38. As expected, the labeling appeared as a fluorescent crescent near the nucleus (inset: scale bar, $5 \mu \mathrm{m}$ ) in untreated slices, whereas the Golgi network was dramatically disorganized in BFA-treated slices. $A, b$, Microtubules were immunolabeled with an antibody directed against $\beta$-tubulin. Nocodazole treatment strongly disrupted the cytoskeleton, as seen by the absence of $\beta$-tubulin detection. $B$, Pooled data showing that treatment with either BFA or nocodazole abolished the increase in LY spreading in hexamethonium-containing medium. ${ }^{*} p<0.01$ compared with control.

junctions are involved in cell-to-cell propagation of electrical events and subsequent $\left[\mathrm{Ca}^{2+}\right]_{\mathrm{i}}$ increases in the adrenal medulla of adult rats (Martin et al., 2001). To address the role of gap junctions in the intercellular transfer of biological signals in neonates, multicellular $\left[\mathrm{Ca}^{2+}\right]_{\mathrm{i}}$ changes were monitored with realtime confocal microscopy in Oregon Green 4800 BAPTA-1loaded chromaffin cells. As illustrated in Figure 7, the triggering of an action potential resulted in a $\left[\mathrm{Ca}^{2+}\right]_{\mathrm{i}}$ rise in the stimulated 

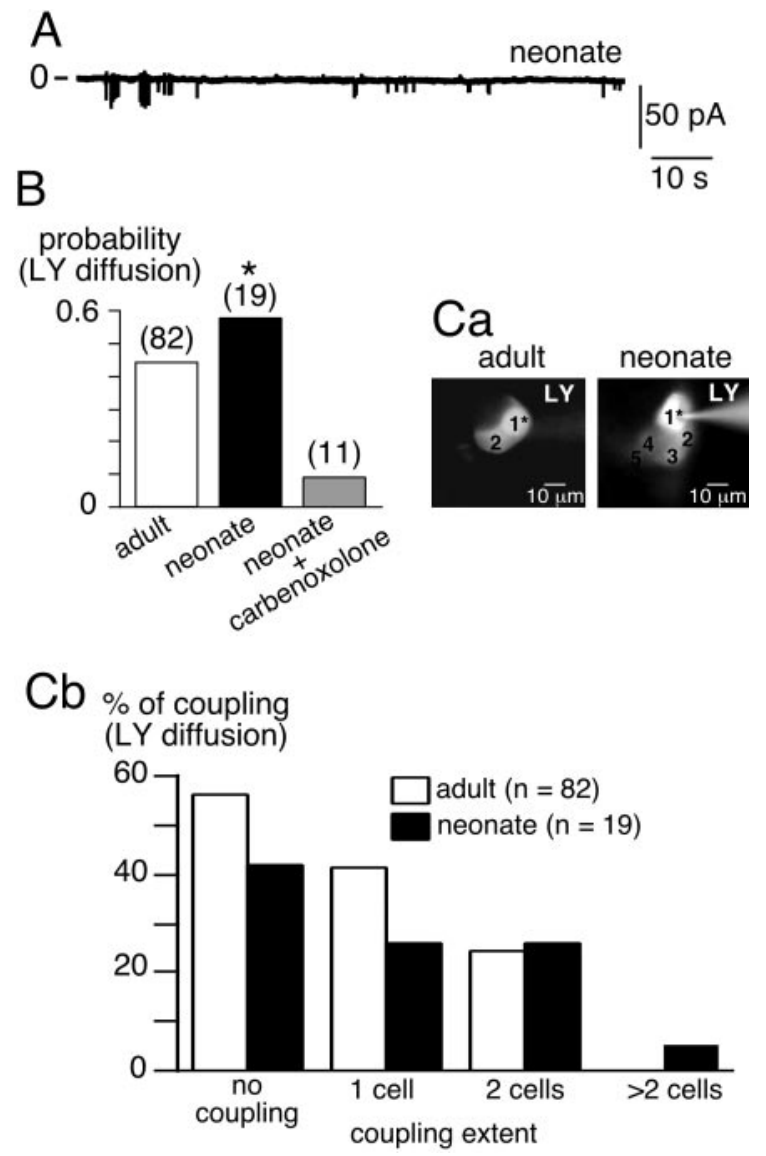

Figure 6. Greater gap junction-mediated intercellular communication between chromaffin cells in neonates. $A$, Chart recording of spontaneous excitatory synaptic activity in chromaffin cells in neonates. $B$, Increased probability of LY diffusion in neonates compared with adults $\left({ }^{*} p<0.01\right)$. $C$, Increase in the extent of coupling in neonates compared with adults. $C, a$, Examples of in situ $L Y$ diffusion between chromaffin cells in adults ( 2 cells) and in neonates (up to 5 cells in the same optical plane). $1^{*}$ represents the patched cell. $c, b$, pooled data.

cell and in several adjacent cells (up to five cells in the same optical plane). Such a simultaneous $\left[\mathrm{Ca}^{2+}\right]_{\mathrm{i}}$ increase in neighboring chromaffin cells in response to depolarization-evoked action potentials was observed in $62.5 \%$ of recorded cell fields $(n=$ 10 of 16), a percentage significantly higher in neonates than in adults $(p<0.01)$ (Martin et al., 2001). In addition, the number of cells in which $\left[\mathrm{Ca}^{2+}\right]_{\mathrm{i}}$ simultaneously increased was higher in the neonate than in the adult. This result is in agreement with the data illustrated in Figure 6C showing enhanced LY diffusion in neonates.

The propagation of action potential-induced $\left[\mathrm{Ca}^{2+}\right]_{\mathrm{i}}$ elevations likely reflects a physiological phenomenon, because synchronized $\left[\mathrm{Ca}^{2+}\right]_{\mathrm{i}}$ transients spontaneously occurred between adjacent chromaffin cells in the absence of stimulation (data not shown). Based on the kinetics of $\left[\mathrm{Ca}^{2+}\right]_{\mathrm{i}}$ transients (i.e., a fastpeaking rising phase followed by a return to baseline within a few seconds), we proposed that these $\left[\mathrm{Ca}^{2+}\right]_{\mathrm{i}}$ transients are likely to reflect $\mathrm{Ca}^{2+}$ entry through voltage-gated $\mathrm{Ca}^{2+}$ channels opening during action potentials.

Long-lasting persistence of the upregulation of gap junctionmediated intercellular coupling between chromaffin cells: a study in splanchnectomized rats

To study the effects of chronic disruption of synaptic activity, we monitored dye coupling in denervated adrenal glands after uni-
A
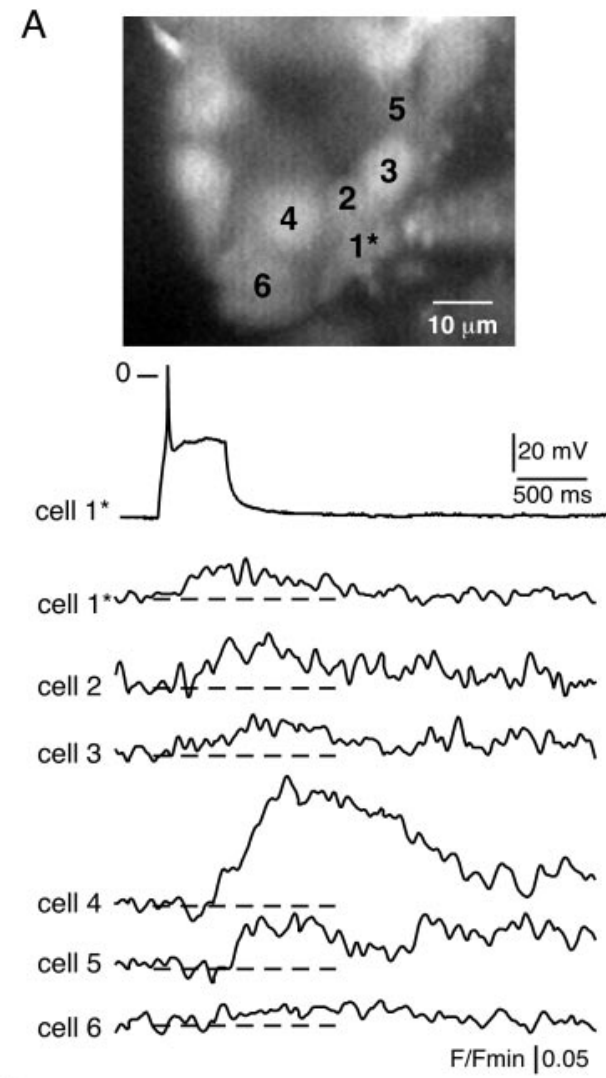

B

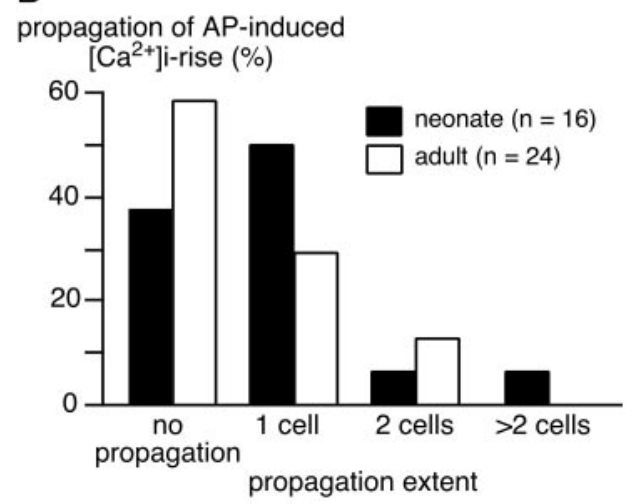

Figure 7. Propagation of electrical activity-linked $\left[\mathrm{Ca}^{2+}\right]_{\mathrm{i}}$ rise between chromaffin cells: a functional role for gap junctions in neonates. $A$, An acute adrenal slice from a neonatal rat was loaded with a $\mathrm{Ca}^{2+}$-sensitive probe to simultaneously image $\left[\mathrm{Ca}^{2+}\right]_{\mathrm{i}}$ changes in multiple neighboring chromaffin cells. The plots of relative Oregon Green 488 BAPTA-1 emission changes show a $\left[\mathrm{Ca}^{2+}\right]_{\mathrm{i}}$ rise in either the stimulated cell $\left(1^{*}\right.$, action potential triggered by an injection of a 500 msec depolarizing current) or in several nearby cells (cells $2-6$ ). Dotted lines indicate the baseline. $B$, Histogram illustrating the percentage of cell fields in which the $\left[\mathrm{Ca}^{2+}\right]_{\mathrm{i}}$ rise was propagated to adjacent cells in neonates and in adults.

lateral lesion of the splanchnic nerve, which represents the preganglionic input to the chromaffin cells. As shown in Figure $8 A$, synaptic transmission was fully disrupted in the denervated medulla 2-4 weeks after surgery, because no more spontaneous synaptic currents occurred (Fig. $8 \mathrm{~A}$, middle trace) ( $n=15$ cells). Furthermore, increasing the external $\mathrm{K}^{+}$concentration to $20 \mathrm{mM}$ to induce a $\mathrm{Ca}^{2+}$ rise in the nerve terminals had no effect on synaptic activity, thus confirming the effectiveness of the denervation (data not shown). In contrast, spontaneous EPSCs persisted in the contralateral adrenal gland (Fig. $8 \mathrm{~A}$, bottom trace), and the percentage of cells exhibiting synaptic events did not 
A

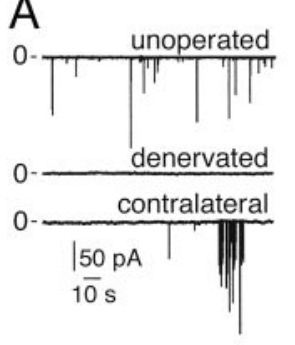

\section{B}

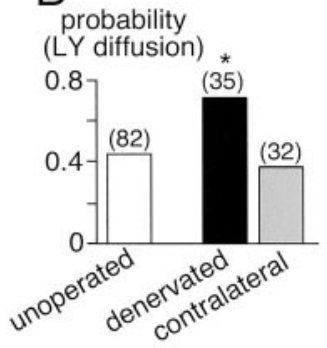

C

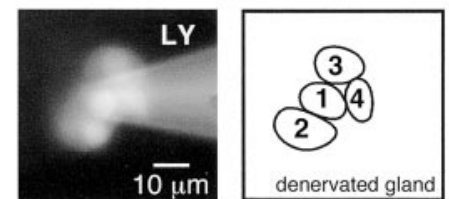

$\%$ of coupling

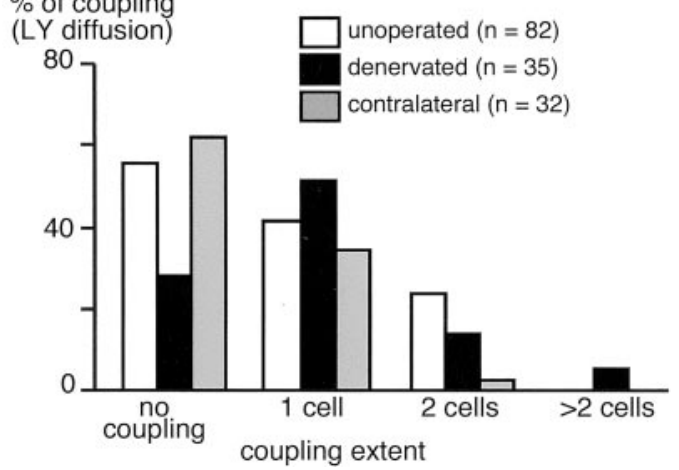

Figure 8. Effect of splanchnectomy on gap junctional coupling in chromaffin cells. A, Spontaneous EPSCs recorded in a control slice (top trace) and in a slice derived from a denervated gland (middle trace) and a contralateral gland (bottom trace). No synaptic activity was detected in the denervated tissue. $B$, Probability of $L Y$ spreading between chromaffin cells after a single cell injection. ${ }^{*} p<0.01$ compared with values in adults. The number of recorded cells is indicated in parentheses. C, Extent of coupling estimated by the number of $L Y$-stained chromaffin cells. Note that the increase in gap junction coupling in the denervated gland was accompanied by an increase in the extent of coupling.

differ from that found in unoperated animals (17.6 vs $12 \%$, respectively; $p>0.01)$. However, the mean EPSC amplitude was $138.5 \pm 9.6 \mathrm{pA}(n=80$, three cells $)$ and was significantly higher when compared with that found in unoperated rats $(p<0.01)$ (Fig. $8 A$, top trace) $(n=9$ cells), although EPSC frequency was not altered $[0.04 \pm 0.02 \mathrm{~Hz}(n=3)$ for contralateral gland vs $0.08 \pm 0.04 \mathrm{~Hz}(n=9)$ for unoperated animals; $p>0.01]$. The probability of dye coupling in splanchnectomized rats was significantly higher in denervated glands $(\sim 0.7)$ compared with either the contralateral gland $(\sim 0.4)$ or glands from unoperated rats $(\sim 0.4)$ (Fig. $8 B)(p<0.01)$. In the denervated adrenal gland, the extent of LY diffusion from the patched cell to a neighboring cell was also significantly increased when compared with the contralateral innervated gland or the glands in unoperated rats (Fig. $8 C)(p<0.01)$.

Taken together, the data obtained from splanchnectomized animals strengthen our hypothesis that synaptic activity tonically controls the degree of gap junction-mediated intercellular communication between chromaffin cells. This modulation, which is likely to involve multiple mechanisms (see Discussion) takes place within $1 \mathrm{hr}$ of disrupting synaptic transmission and appears to persist for several weeks.

\section{Discussion}

We show here that the gap junction-mediated coupling between rat adrenal chromaffin cells is dynamically regulated by the functional state of excitatory nicotinic synaptic transmission. Experimental conditions in which postsynaptic nAChRs are weakly stimulated or blocked (acute pharmacological blockade of nAChRs, surgically induced adrenal denervation, or immature nicotinic synaptic transmission in neonates) lead to a significant increase in dye coupling between chromaffin cells. This suggests that synaptic inputs, when cholinergic transmission is normal or mature, exert a tonic inhibitory effect on gap junction-mediated communication. Together, the present study provides strong support for our previously proposed hypothesis, according to which gap junction-mediated signaling and synaptic transmission act in a coordinated manner to ensure normal cell function (Martin et al., 2001).

\section{The trafficking machinery as a possible mediator of upregulated gap junctional coupling after blockade of nicotinic synaptic transmission}

Dye coupling experiments performed in the presence of bathapplied nAChR antagonists show that the gap junctiondependent networks between chromaffin cells rapidly respond (within $1 \mathrm{hr}$ ) to modifications in nicotinic synaptic transmission efficiency. As revealed by the recording of the junctional current $I_{\mathrm{j}}$, the enhanced dye coupling observed in nAChR antagonistcontaining saline is associated with an increase in macroscopic gap junctional conductance $\left(G_{\mathrm{j}}\right)$. We propose two hypotheses, which are not mutually exclusive, to account for this finding: an increase in the mean open probability of unitary gap junction channels and/or a change in the number or composition of channels. Although we cannot definitively rule out an effect on the open probability, our data with BFA or nocodazole strongly implicate connexon trafficking or scaffolding protein or connexon trafficking-associated regulatory proteins (Giepmans and Moolenaar, 1998; Toyofuku et al., 1998, 2001; Barker et al., 2002) in the increased expression of gap junctions. The present study does not allow us to identify the intracellular components targeted by nAChR antagonists. Nevertheless, the following mechanisms can be considered. Connexon trafficking involves both their delivery from the TGN to the plasma membrane and their internalization/degradation via proteasomal and lysosomal pathways (Lampe, 1994). The rapid insertion (within $<1 \mathrm{hr}$ ) of existing "nascent" connexons into the chromaffin cell membrane seems plausible, given that the delivery of newly synthetized connexons from the Golgi complex to the plasma membrane can occur within $2 \mathrm{hr}$ (Lauf et al., 2002).

This delivery step, which, as shown for connexin 43 (Cx43) (Giepmans et al., 2001), depends on a direct interaction with the microtubules, may be a target for modulation by nicotinic receptor signaling. Our results with nocodazole would be consistent with such an effect on microtubule function. Because gap junctions are constantly being renewed and rapidly turned over (Fallon and Goodenough, 1981; Laird, 1996), gap junction assembly at the plasma membrane may be subject to regulation at the level of connexin turnover (Musil et al., 2000). Reduction in connexin cycling could therefore increase gap junctional coupling by reducing endocytic traffic of connexins. Alternatively, connexon assembly at the plasma membrane may be affected by nicotinic receptor signaling. The assembly process is dynamically regulated by connexin phosphorylation (Cooper and Lampe, 2002) as well as by microtubules (Johnson et al., 2002) and by adhesion molecules such as $\alpha$-catenin (Govindarajan et al., 2002). An additional 
mechanism to account for the increase in gap junctional conductance may be a change in the subunit composition of the connexons. Such a remodeling would imply that new connexins with a high unitary conductance would preferentially replace existing connexins. A good candidate for a high-conductance connexin would be $\mathrm{Cx} 43$, which is expressed in rat adrenal chromaffin cells (Martin et al., 2001).

Because slices were bathed with $\mathrm{nAChR}$ antagonists for at least $30 \mathrm{~min}$ before dye coupling experiments or $I_{j}$ measurement, very short-term effects of the blockers on the biophysical properties of gap junction channels were not investigated. Recordings of unitary electrical activity from gap junction channels would be required to definitively address this issue. Nevertheless, we cannot exclude the possibility that intracellular second messengers $\left(\mathrm{Ca}^{2+}\right.$ and downstream $\mathrm{Ca}^{2+}$-dependent kinases or phosphatases) may also affect the gating properties of gap junctions (Lampe and Lau, 2000).

\section{Long-term persistence of changes in gap junction-mediated communication}

Our experiments on splanchnectomized rats indicate that upregulation of gap junctional coupling can persist for as long as synaptic activity is impaired (at least 3 weeks in this study). This result clearly shows that gap junctional coupling present in adults can undergo both short-term changes, as reported previously, and long-term changes. Such prolonged effects on gap junctional coupling are consistent with a previous study showing that the re-establishment of gap junctional coupling after injury can persist for many weeks (Chang et al., 2000). In splanchnectomized animals, sustained changes in sympathetic transmission may affect the level of mRNA encoding connexins (or other proteins interacting with connexins), as reported for tyrosine hydroxylase activity after chemical sympathectomy (Mueller et al., 1969). Such a compensatory increase in connexin-encoded gene activity could lead to long-term upregulation in the number of gap junction plaques between chromaffin cells. Additional approaches, including immunostaining and in situ hybridization in the denervated adrenal gland, will be required to evaluate this hypothesis. Alternatively, splanchnectomy may result in the modulation of connexin assembly into functional channels and/or the modification of existing gap junction plaques (Chang et al., 2000).

\section{Roles of gap junctions between chromaffin cells in neonates: gap junctions as relays before the establishment of functional synaptic inputs}

It is known that at birth, synaptic transmission between the splanchnic nerve and chromaffin cells is not fully competent (Millar and Unsicker, 1981; Slotkin, 1986), although presynaptic and postsynaptic elements are already present prenatally (Daikoku et al., 1977). From a functional point of view, we show here that the main difference observed in neonatal tissue compared with adults was a reduction in EPSC amplitude. Under the same experimental conditions, gap junctional coupling was upregulated. Furthermore, we found that action potential-induced $\left[\mathrm{Ca}^{2+}\right]_{\mathrm{i}}$ increases imaged in multiple cells resulted in synchronized signal propagation between nearby chromaffin cells, demonstrating that gap junctions are functional. Because transsynaptic transmission is not fully functional at birth, other processes are likely to mediate catecholamine release in neonatal rats. Intercellular communication mechanisms between chromaffin cells within the medulla would be good candidates. Although paracrine and/or endocrine interactions cannot be definitively ruled out, our finding that altered synaptic activity leads to an increase in gap junction coupling strongly suggests that this mode of communication contributes to catecholamine release in neonates. Gap junctions would thus act as a substitute for chemical synaptic transmission, thereby compensating for reduced synaptic activity. This hypothesis is consistent with the fact that gap junction-coupled neuronal assemblies often precede synaptically connected networks (Kandler, 1997), and that the expression of gap junctions gradually decreases during postnatal development, coinciding with the establishment of functional synapses (Personius and Balice-Gordon, 2001; Mentis et al., 2002).

\section{Functional significance of an interaction between synaptic transmission and gap junction coupling in the adrenal medulla}

This study strengthens our view that a prominent interplay between cholinergic synaptic activity and gap junctional coupling is necessary for normal function of the rat adrenal medulla. Coordination of cellular responses is crucial in maintaining syncytial function in various tissues. The innervation density, the frequency of stimulation, and the extent of intercellular coupling are among the parameters that must be integrated for normal activity, as modeled recently (Ramanan et al., 1998). Finally, we propose that the modulation of gap junction coupling is important under pathological conditions in which synaptic transmission is reduced. By compensating for the loss in chemical neurotransmission, gap junction signaling could sustain catecholamine release by maintaining communication within the chromaffin cell network.

\section{References}

Axelrod J (1971) Noradrenaline: fate and control of its synthesis. Science 173:598-606

Barbara JG, Takeda K (1996) Quantal release at a neuronal nicotinic synapse from rat adrenal gland. Proc Natl Acad Sci USA 93:9905-9909.

Barker RJ, Price RL, Gourdie RG (2002) Increased association of ZO-1 with connexin43 during remodeling of cardiac gap junctions. Circ Res 90:317-324.

Bonnefont X, Fiekers J, Creff A, Mollard P (2000) Rhythmic bursts of calcium transients in acute anterior pituitary slices. Endocrinology 141:868-875.

Chang Q, Pereda A, Pinter MJ, Balice-Gordon RJ (2000) Nerve injury induces gap junctional coupling among axotomized adult motor neurons. J Neurosci 20:674-684.

Cooper CD, Lampe PD (2002) Casein kinase 1 regulates connexin-43 gap junction assembly. J Biol Chem 277:44962-44968.

Criado M, Dominguez del Toro E, Carrasco-Serrano C, Smillie FI, Juiz JM, Viniegra S, Ballesta JJ (1997) Differential expression of $\alpha$-bungarotoxinsensitive neuronal nicotinic receptors in adrenergic chromaffin cells: a role for transcription factor Egr-1. J Neurosci 17:6554-6564.

Daikoku S, Kinutani M, Sako M (1977) Development of the adrenal medullary cells in rats with reference to synaptogenesis. Cell Tissue Res 179:77-86

Di Angelantonio S, Nistri A, Moretti M, Clementi F, Gotti C (2000) Antagonism of nicotinic receptors of rat chromaffin cells by $N, N, N$-trimethyl1-(4-trans-stilbenoxy)-2-propylammonium iodide: a patch clamp and ligand binding study. Br J Pharmacol 129:1771-1779.

Dinter A, Berger EG (1998) Golgi-disturbing agents. Histochem Cell Biol 109:571-590.

Fallon RF, Goodenough DA (1981) Five-hour half-time of mouse liver gapjunction protein. J Cell Biol 90:521-526.

Giepmans BN, Moolenaar WH (1998) The gap junction protein connexin43 interacts with the second PDZ domain of the zona occludens-1 protein. Curr Biol 8:931-934.

Giepmans BN, Verlaan I, Hengeveld T, Janssen H, Calafat J, Falk MM, Moolenaar WH (2001) Gap junction protein connexin-43 interacts directly with microtubules. Curr Biol 11:1364-1368.

Gotti C, Balestra B, Moretti M, Rovati GE, Maggi L, Rossoni G, Berti F, Villa L, Pallavicini M, Clementi F (1998) 4-oxystilbene compounds are selec- 
tive ligands for neuronal $\alpha$-bungarotoxin receptors. $\mathrm{Br} \mathrm{J}$ Pharmacol 124:1197-1206.

Govindarajan R, Zhao S, Song XH, Guo RJ, Wheelock M, Johnson KR, Mehta PP (2002) Impaired trafficking of connexins in androgen-independent human prostate cancer cell lines and its mitigation by $\alpha$-catenin. J Biol Chem 277:50087-50097.

Guérineau NC, Bonnefont X, Stoeckel L, Mollard P (1998) Synchronized spontaneous $\mathrm{Ca}^{2+}$ transients in acute anterior pituitary slices. J Biol Chem 273:10389-10395.

Hamill OP, Marty A, Neher E, Sakmann B, Sigworth FJ (1981) Improved patch-clamp techniques for high-resolution current recording from cells and cell-free membrane patches. Pflügers Arch 391:85-100.

Hatton GI (1997) Function-related plasticity in hypothalamus. Annu Rev Neurosci 20:375-397.

Hatton GI (1998) Synaptic modulation of neuronal coupling. Cell Biol Int 22:765-780.

Hatton GI, Yang QZ (1996) Synaptically released histamine increases dye coupling among vasopressinergic neurons of the supraoptic nucleus: mediation by $\mathrm{H}_{1}$ receptors and cyclic nucleotides. J Neurosci 16:123-129.

Hatton GI, Yang QZ (2001) Ionotropic histamine receptors and $\mathrm{H}_{2}$ receptors modulate supraoptic oxytocin neuronal excitability and dye coupling. J Neurosci 21:2974-2982.

Haydon PG (2001) Glia: listening and talking to the synapse. Nat Rev Neurosci 2:185-193.

Helms JB, Rothman JE (1992) Inhibition by brefeldin A of a Golgi membrane enzyme that catalyses exchange of guanine nucleotide bound to ARF. Nature 360:352-354.

Ishimatsu M, Williams JT (1996) Synchronous activity in locus ceruleus results from dendritic interactions in pericoerulear regions. J Neurosci 16:5196-5204.

Johnson RG, Meyer RA, Li XR, Preus DM, Tan L, Grunenwald H, Paulson AF, Laird DW, Sheridan JD (2002) Gap junctions assemble in the presence of cytoskeletal inhibitors, but enhanced assembly requires microtubules. Exp Cell Res 275:67-80.

Kandler K (1997) Coordination of neuronal activity by gap junctions in the developing neocortex. Cell Dev Biol 8:43-51.

Klausner RD, Donaldson JG, Lippincott-Schwartz J (1992) Brefeldin A: insights into the control of membrane traffic and organelle structure. J Cell Biol 116:1071-1080.

Lagostena L, Ashmore JF, Kachar B, Mammano F (2001) Purinergic control of intercellular communication between Hensen's cells of the guinea-pig cochlea. J Physiol (Lond) 531:693-706.

Laird DW (1996) The life cycle of a connexin: gap junction formation, removal, and degradation. J Bioenerg Biomembr 28:311-318.

Lampe PD (1994) Analyzing phorbol ester effects on gap junctional communication: a dramatic inhibition of assembly. J Cell Biol 127:1895-1905.

Lampe PD, Lau AF (2000) Regulation of gap junctions by phosphorylation of connexins. Arch Biochem Biophys 384:205-215.

Lauf U, Giepmans BN, Lopez P, Braconnot S, Chen SC, Falk MM (2002) Dynamic trafficking and delivery of connexons to the plasma membrane and accretion to gap junctions in living cells. Proc Natl Acad Sci USA 99:10446-10451.

Luzio JP, Brake B, Banting G, Howell KE, Braghetta P, Stanley KK (1990) Identification, sequencing and expression of an integral membrane protein of the trans-Golgi network (TGN38). Biochem J 270:97-102.

Martin AO, Mathieu MN, Chevillard C, Guérineau NC (2001) Gap junctions mediate electrical signaling and ensuing cytosolic $\mathrm{Ca}^{2+}$ increases between chromaffin cells in adrenal slices: a role in catecholamine release. J Neurosci 21:5397-5405.

McMahon DG, Mattson MP (1996) Horizontal cell coupling in the giant danio: synaptic modulation by dopamine and synaptic maintenance by calcium. Brain Res 718:89-96.

Mentis GZ, Díaz E, Moran LB, Navarrete R (2002) Increased incidence of gap junctional coupling between spinal motoneurones following tran- sient blockade of NMDA receptors in neonatal rats. J Physiol (Lond) 544:757-764.

Millar TJ, Unsicker K (1981) Catecholamine-storing cells in the adrenal medulla of the pre- and postnatal rat. Cell Tissue Res 217:155-170.

Mousavi M, Hellström-Lindahl E, Guan ZZ, Bednar I, Nordberg A (2001) Expression of nicotinic acetylcholine receptors in human and rat adrenal medulla. Life Sci 70:577-590.

Mueller RA, Thoenen H, Axelrod J (1969) Compensatory increase in adrenal tyrosine hydroxylase activity after chemical sympathectomy. Science 163:468-469.

Musil LS, Le AC, VanSlyke JK, Roberts LM (2000) Regulation of connexin degradation as a mechanism to increase gap junction assembly and function. J Biol Chem 275:25207-25215.

Neyton J, Trautmann A (1985) Single-channel currents of an intercellular junction. Nature 317:331-335.

Nooney JM, Feltz A (1995) Inhibition by cyclothiazide of neuronal nicotinic responses in bovine chromaffin cells. Br J Pharmacol 114:648-655.

Pereda A, Triller A, Korn H, Faber DS (1992) Dopamine enhances both electrotonic coupling and chemical excitatory postsynaptic potentials at mixed synapses. Proc Natl Acad Sci USA 89:12088-12092.

Personius KE, Balice-Gordon RJ (2001) Loss of correlated motor neuron activity during synaptic competition at developing neuromuscular synapses. Neuron 31:395-408.

Piccolino M, Neyton J, Witkovsky P, Gerschenfeld HM (1982) $\gamma$-Aminobutyric acid antagonists decrease junctional communication between L-horizontal cells of the retina. Proc Natl Acad Sci USA 79:3671-3675.

Piccolino M, Neyton J, Gerschenfeld HM (1984) Decrease of gap junction permeability induced by dopamine and cyclic adenosine $3^{\prime}: 5^{\prime}$ - monophosphate in horizontal cells of turtle retina. J Neurosci 4:2477-2488.

Ramanan SV, Brink PR, Christ GJ (1998) Neuronal innervation, intercellular signal transduction and intercellular coupling: a model for syncytial tissue responses in the steady state. J Theor Biol 193:69-84.

Rozental R, Srinivas M, Gokhan S, Urban M, Dermietzel R, Kessler JA, Spray DC, Mehler MF (2000) Temporal expression of neuronal connexins during hippocampal ontogeny. Brain Res Brain Res Rev 32:57-71.

Rust G, Burgunder J-M, Lauterburg TE, Cachelin AB (1994) Expression of neuronal nicotinic acetylcholine receptor subunit genes in the rat autonomic nervous system. Eur J Neurosci 6:478-485.

Schmitz D, Schuchmann S, Fisahn A, Draguhn A, Buhl EH, Petrasch-Parwez E, Dermietzel R, Heinemann U, Traub RD (2001) Axo-axonal coupling: a novel mechanism for ultrafast neuronal communication. Neuron 31:831-840.

Shinohara K, Hiruma H, Funabashi T, Kimura F (2000) GABAergic modulation of gap junction communication in slice cultures of the rat suprachiasmatic nucleus. Neuroscience 96:591-596.

Sine SM (1997) Identification of equivalent residues in the gamma, delta, and epsilon subunits of the nicotinic receptor that contribute to alphabungarotoxin binding. J Biol Chem 272:23521-23527.

Slotkin TA (1986) Development of the sympathoadrenal axis. In: Developmental neurobiology of the autonomic nervous system (Gootman PM, ed), pp 69-96. Totowa, NJ: Humana.

Tomlinson A, Coupland RE (1990) The innervation of the adrenal gland. IV. Innervation of the rat adrenal medulla from birth to old age. A description and quantitative morphometric biochemical study of the innervation of the chromaffin cells and adrenal medullary neurons in Wistar rats. J Anat 169:209-236.

Toyofuku T, Yabuki M, Otsu K, Kuzuya T, Hori M, Tada M (1998) Direct association of the gap junction protein connexin- 43 with ZO-1 in cardiac myocytes. J Biol Chem 273:12725-12731.

Toyofuku T, Akamatsu Y, Zhang H, Kuzuya T, Tada M, Hori M (2001) c-Src regulates the interaction between connexin- 43 and $\mathrm{ZO}-1$ in cardiac myocytes. J Biol Chem 276:1780-1788.

Zimmermann H (1994) Signalling via ATP in the nervous system. Trends Neurosci 17:420-426. 